\title{
The effect of ruminal infusion of acetic acid on eating and rumination behaviour in sheep fed on various hay diets
}

\author{
T. Fujihara' ${ }^{1}$ T. Harumoto and S.A. Abdulrazak ${ }^{2}$ \\ Faculty of Life and Environmental Science, Shimane University \\ Matsue-shi, Shimane 690-8504, Japan
}

(Received 14 May 2001; revised version 26 November 2001; accepted 3 I January 2002)

\begin{abstract}
The present study was carried out to investigate the effect of ruminal infusion of acetic acid on rumination behaviour in sheep fed on the hay diets with varied crude protein (CP) content. ltalian ryegrass, timothy and lucerne hays were used and their CP content was 7.3,10.4 and 14.9, respectively. Acetic acid with buffer, total amount of $1,000 \mathrm{ml}$, was infused at a rate of $62 \mathrm{mmol}$ per hour $(300$ $\mathrm{kcal} /$ day) into the rumen of wethers fed $2.0 \%$ of dry matter (DM) of body weight per day. The obtained results were as follows: 1 , the digestibility of organic matter and nitrogen-free extractives (NFE) tended to decrease with the infusion of acetic acid regardless of the hay diets-CP content consumed, but not significantly $(P>0.05) ; 2$. time spent eating was significantly $(P<0.05)$ prolonged with acid infusion in sheep fed on timothy or lucerne hays, and consequently, rate of eating was also significantly $(P<0.05)$ slow, although there was no significant $(P>0.05)$ effect of acid infusion in sheep fed on Italian ryegrass hay; 3 . daily time spent ruminating and daily number of boli in sheep fed on timothy or lucerne hay also tended to increase $(\mathrm{P}<0.05)$ after infusion of acid, though there was no changes in sheep fed Italian ryegrass hay with ruminal infusion of acetic acid; 4 . cyclic rate was significantly $(\mathrm{P}<0.05)$ shorter in shecp fed luccrne hay with acid infusion than in control, whereas it was almost the same in sheep fed on Italian ryegrass or timothy hay with or without acid infusion; 5 . the rumination index was aiso lengthened $(\mathrm{P}<0.05)$ after acid infusion in sheep fed on timothy or lucerne hay, though in sheep fed on Italian ryegrass hay with acid infusion had no effect on rumination index. From these results, it can be concluded that the effect of ruminal infusion of acetic acid on fibre digestibility of hay diet could have a much more strong influence on the control to microbial activity than on comminuting the feed particles through remastication during the ruminating period.
\end{abstract}

KEY WORDS: rumination behaviour, sheep, acetic acid infusion, dictary nitrogen level

1 Corresponding author

2 Present address: Department of Animal Science, Egerton University, P.O. Box 536, Njoro, Kenya 


\section{INTRODUCTION}

It has been well known that the rumination behaviour is closely related with the utilization of feed, in particular roughages, and the physical property of feed also influences on eating and rumination behaviour in sheep and cattle (Pearce and Moir, 1965; Fujihara, 1980; Itabisashi, 1987). On the other hand, the chemical characteristics of feed is also thought to be a major factor influencing eating and rumination behaviour through the changes of microbial activity in the rumen (Tasaki et al., 1983; Fujihara and Nakao, 1990a,b).

In order to investigate the effect of chemical change in diet on rumination behaviour, there is little information using sheep with ruminal infusion of volatile fatty acids (VFAs)(Egan and Moir, 1965). In a paper by Fujihara et al. (2002), the ruminal infusion of acetic acid or propionic acid did not have clear effect on eating and ruminating behaviour, although there were obvious effect of nitrogen balance after infusion of acetic acid, in sheep fed on a low quality hay.

In the present experiment, the effect of ruminal infusion of acetic acid on digestibility of feed and eating and rumination behaviour was investigated in sheep fed a various hay diets with differing the nitrogen contents. Part of this work has been briefly described by Fujihara et al. (1990).

\section{MATERIAL AND METHODS}

\section{Animals and their management}

Two Japanese Corriedale wethers with rumen fistula, weighing 39.5 and $41.1 \mathrm{~kg}$, were used repeatedly. They were kept in metabolism cages throughout the experimental period, and fed Italian ryegrass, timothy or lucerne hay at a level of $2.0 \%$ dry matter (DM) of body weight per day. The hay was cut to about $10 \mathrm{~cm}$ long before feeding. Chemical composition (as \% DM) of hays was shown in Table 1. Fresh water and salt licks containing trace elements were available at all time. One-half of the daily rations was offered at 09.00 and the other half at 17.00 .

\section{Treatment and design}

Acetic acid with buffer was ruminally infused at a rate of $62 \mathrm{mmol}$ per hour during $24 \mathrm{~h}$, supplying $300 \mathrm{kcal}$ per day per head, which was within a range of the acid, ordinary by expected in the rumen. The composition of buffer was the same as that used in the study (Fujihara et al., 2002). The acetic acid solution was $1,000 \mathrm{ml}$ as a total, and was continuously infused into the rumen with a peristaltic pump (Tokyo Rika Co., Tokyo, Japan) for $24 \mathrm{~h}$. A crossover design was adopted for treatment (acetic acid infusion) and control in each trial (Table 2). 
TABLE 1

Chemical composition of hay diet, \% of DM

\begin{tabular}{lccc}
\hline Diet & Italian ryegrass & Timolhy & Lucerne \\
\hline Organic matter & 87.1 & 87.1 & 90.2 \\
Crude protein & 7.3 & 10.6 & 14.9 \\
Crude fat & 2.8 & 3.7 & 4.1 \\
Crude fibre & 37.8 & 25.1 & 24.8 \\
NFE* $^{*}$ & 39.3 & 47.6 & 46.7 \\
\hline
\end{tabular}

* nitrogen frec extractives

TABLE 2

Experimental design

\begin{tabular}{|c|c|c|c|c|c|c|}
\hline \multirow{3}{*}{$\begin{array}{l}\text { Basal diet } \\
\text { Treatment }\end{array}$} & \multicolumn{2}{|c|}{ Period 1} & \multicolumn{2}{|c|}{ Period II } & \multicolumn{2}{|c|}{ Period IIl } \\
\hline & \multicolumn{2}{|c|}{ Italian rycgrass } & \multicolumn{2}{|c|}{ Timothy } & \multicolumn{2}{|c|}{ Lucerne } \\
\hline & control & infusion $^{* *}$ & control & infusion & control & infusion \\
\hline \multicolumn{7}{|c|}{ Allocation of animals } \\
\hline $\mathrm{l}^{*} \operatorname{term}^{*}$ & A & B & A & $\mathrm{B}$ & A & B \\
\hline $2^{\text {nde }}$ term & B & A & B & A & B & A \\
\hline
\end{tabular}

Sample collection and analytical methods

In each experimental period as shown in Table 2, a 5-day sampling period was preceded by a 7-day preliminary period, and faeces were collected daily just before morning feed.

The time spent chewing during eating and ruminating were measured daily by the method of Fujihara (1980) using a wire strain gauge on the lower jaw of animals (Harumoto and Kato, 1979) during 5-day sampling period in each trial. The terms used in this paper to indicate the rumination behaviour are the same as in the previous report of Fujihara (1981) based on the work of Gordon (1955).

Nitrogen in the diets and faeces was analyzed by the Kjeldahl method, and the contents of crude fat, crude fibre and crude ash in the diets and faeces were determined by AOAC method (1960).

Test of significance between two groups (acid infusion and control) was done by t-1est. 


\section{RESULTS}

\section{Diets and apparent digestibility}

Crude protein (CP) contents of timothy and lucerne hays were about 1.5 and 2.0 times higher than that of Italian ryegrass hay, respectively (Table 1). On the other hand, crude fibre contents of timothy and lucerne hays were about $10 \%$ lower than that of Italian ryegrass hay.

Table 3 shows apparent digestibility of nutrients in sheep fed the three hays with or without ruminal infusion of acetic acid. Digestibility of organic matter (OM) of each hay diet tended to decrease after acetic acid infusion as compared with that in control, but not significantly $(\mathrm{P}>0.05)$. The digestibility of $\mathrm{CP}$ in Italian ryegrass and timothy hays tended to be higher after acetic acid infusion than that in control, but not significantly $(\mathrm{P}>0.05)$, whereas in lucerne hay there was no difference in protein digestibility with or without acetic acid infusion. The digestibility of crude fat and crude fibre in all the hay diets were not influenced after intraruminal infusion of acetic acid. Digestibility of nitrogen-free extractives (NFE) in all the hay diets tended to be lower after acetic acid infusion as compared with that of control, but not significantly $(\mathrm{P}>0.05)$.

TABLE 3 Apparent digestibility of nutrients in sheep fed various hay diets with ruminal infusion of acetic acid

\begin{tabular}{|c|c|c|c|c|c|c|}
\hline \multirow{2}{*}{ Diel } & \multicolumn{2}{|c|}{ Italian rycgrass } & \multicolumn{2}{|c|}{ Timothy } & \multicolumn{2}{|c|}{ Lucerne } \\
\hline & control & infusion & control & infusion & control & infusion \\
\hline Organic matter & $55.0 \pm 0.4^{*}$ & $51.2 \pm 1.3$ & $59.6 \pm 0.5$ & $56.4 \pm 2.0$ & $63.2 \pm 0.0$ & $62.9 \pm 0.1$ \\
\hline Crude protein & $50.1 \pm 0.3$ & $46.0 \pm 0.1$ & $71.8 \pm 0.6$ & $68.1 \pm 2.0$ & $76.2 \pm 0.0$ & $76.6 \pm 0.2$ \\
\hline Crude fat & $59.7 \pm 6.4$ & $59.8 \pm 6.2$ & $64.1 \pm 1.6$ & $64.2 \pm 0.5$ & $60.4 \pm 1.3$ & $62.5 \pm 1.2$ \\
\hline Crude fibre & $64.0 \pm 0.4$ & $59.5 \pm 1.4$ & $49.1 \pm 2.7$ & $45.4 \pm 4.1$ & $33.6 \pm 1.2$ & $34.0 \pm 0.8$ \\
\hline $\mathrm{NFE}^{* *}$ & $46.8 \pm 0.4$ & $43.6 \pm 1.1$ & $62.1 \pm 0.5$ & $59.2 \pm 2.6$ & $74.5 \pm 0.1$ & $73.6 \pm 0.2$ \\
\hline
\end{tabular}

* mean $\pm S$. E. of 10 samples ( 2 animals $X 5$ days)

* nitrogen free extractives

\section{Eating behaviour}

Daily time spent eating (Table 4) Italian ryegrass hay was almost similar after infusion of acetic acid as compared with that of control, whereas that of timothy and lucerne hays tended to be longer after infusion of acetic acid than that in control, and the difference between acid infusion and control after feeding lucerne hay was significant $(\mathrm{P}<0.05)$. 
TABLE 4

Eating behaviour in sheep fed various hay diets with ruminal infusion of acetic acid

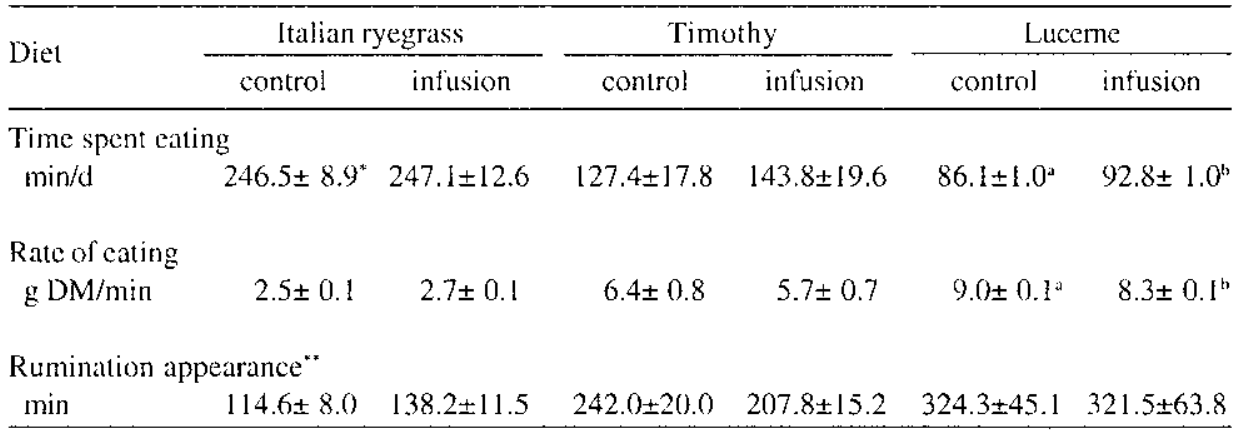

" mean \pm S. E. of 10 observations ( 2 animals $X 5$ days)

** lag time after eating (see Fujihara, 1980a)

a.b difference between control and infusion is significant at $\mathrm{P}<0.05$

Eating rate (g DM/min) after feeding Italian ryegrass hay did not change with an infusion of acetic acid, contrarily, it tended to be longer with intraruminal infusion of acetic acid after feeding timothy and lucerne hays. After feeding lucerne hay the difference between the acid treated group and control was significant $(\mathrm{P}<0.05)$.

Rumination appearance (lag time after feeding) tended to be longer after infusion of acetic acid in sheep fed Italian ryegrass hay, whereas in sheep fed timothy hay it tended to be shorter after infusion of acid than that in control, but not significantly $(\mathrm{P}>0.05)$. When the sheep were fed on lucerne hay, rumination appearance was almost similar in both the acid infusion and no acid infusion groups.

\section{Rumination behaviour}

Daily time spent ruminating in sheep fed Italian ryegrass hay was not influenced by intraruminal infusion of acetic acid, whereas it was significantly $(\mathrm{P}<0.05)$ increased with intraruminal infusion of acetic acid in sheep fed timothy and lucerne hays (Table 5). The number of boli regurgitated per day did also not change with or without intraruminal infusion of acetic acid in sheep fed Italian ryegrass hay. However, when sheep were fed timothy and lucerne hays there was significantly $(P<0.05)$ more boli regurgitated after infusion of acetic acid than in control.

Daily number of rumination periods did not change with acetic acid infusion in sheep fed any of the hay diets. Cyclic rate (total rumination time (s) / number of boli regurgitated) did not change after infusion of acetic acid in sheep fed Italian ryegrass and timothy hays, although when lucerne hay was fed intraruminal infusion of acetic acid had a significantly $(\mathrm{P}<0.05)$ prolonged cyclic rate. 
$\mathrm{C}_{2}$ ACID INFUSION AND RUMINATION BEHAVIOUR

TABLE 5

Rumination behaviour in sheep fed various hay diet with ruminal infusion of acetic acid

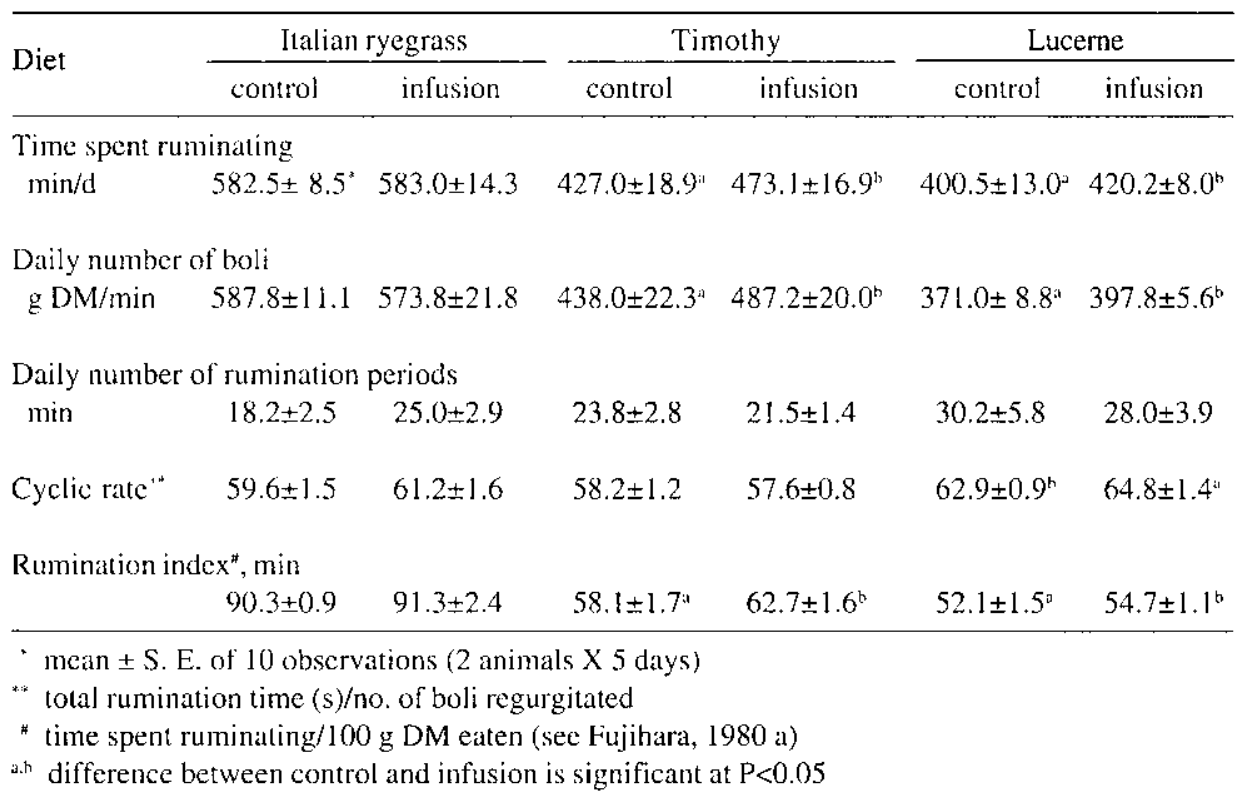

Rumination index (min/100 g DM eaten) (Fujihara, 1980) was the same with or without acetic acid infusion in sheep fed Italian ryegrass hay, whereas it was significantly $(\mathrm{P}<0.05)$ longer in sheep fed timothy and lucerne hays.

\section{DISCUSSION}

In the present experiment, three hays, which had different $\mathrm{CP}$ contents, influenced the nitrogen intake by sheep, (i.e., the CP contents in Italian ryegrass, timothy hay and lucerne hays was 7.0, 10.6 and 14.9\%, respectively). On the other hand, the contents of crude fibre in each hay was $37.8,25.1$ and $24.8 \%$, respectively. Total digestible nutrients (TDN) was $50.0,54.8$ and $60.1 \%$ in Italian ryegrass, timothy and lucerne hays, respectively, resulting varied energy intake from diet in sheep. Probably the digestibilities of OM and NFE were decreased by depressed microbial activity in the rumen due to the effect of acetic acid infusion even when the level of nitrogen intake was changed.

There was a decrease in fibre digestion in the rumen due to the decreased time for microbial degradation caused by an increase in passage rate of digesta through the digestive tracts (Campling and Freer, 1966). Another reason would be due to a 
decrease of microbial activity itself, in the rumen (Ørskov, 1987). In the present study, the digestibility of crude fibre was decreased with acetic acid infusion after feeding Italian ryegrass and timothy hays, though there was no change in digestibility of crude fibre with acetic acid infusion after fecding lucerne hay. On the other hand, as shown in Table 5, daily time spent ruminating tended to be longer with acetic acid infusion. It has also been reported that the ruminal infusion of acetic acid clearly decreased motility of the rumen (Gregory, 1984). This could account for the lengthened a retention time of digesta in the rumen with ruminal infusion of acetic acid. Likewise, the reduction of fibre digestibility in sheep fed on Italian ryegrass and timothy hays and infused with acetic acid could have been due to the decrease in microbial activity in the rumen, because in the report of Fujihara et al. (2002), it was suggested that the infusion of acetic acid could decreases the $\mathrm{pH}$ and the activity of microbes, in particular cellulolytic bacteria, in the rumen. Stewart (1975) reported in vitro experiment that an addition of $90 \mathrm{mM}$ acetic acid had clearly prevented the increase of Ruminicola, one of cellulolytic bacteria in the rumen. In the present experiment, it was also expected the acetic acid infused could have led the decreased $\mathrm{pH}$ and/or the activity of microbes directly or indirectly, and consequently, the fibre digestibility was reduced after feedings Italian ryegrass and timothy hays. On the other hand, the ruminal infusion of acetic acid did not have a clear effect on the fibre digestibility of lucerne hay in this experiment. This is because generally, the digestibility of fibre in legumes is rclatively low as compared to that in grasses due to a relatively high lignin content in the former (Nakamura, 1980). This would be a reason why the ruminal infusion of acetic acid did not have a clear affect on fibre digestibility after feeding lucerne hay. The digestibility of crude fat was not changed with ruminal infusion of acetic acid in all the fed hays, and in particular for Italian ryegrass and timothy hay, although the digestibilities in other nutrients were fairly decreased after acetic acid infusion. Taylor (1962) has observed a secretion of pancreatic juice with infusion of acetic acid into the rumen of sheep. In the present study, it can be presumed that the secretion of lipase from the pancreas was stimulated with ruminal infusion of acetic acid, and the crude fat digestibility did not changed, although acetic acid infused into the rumen might prevent in some extent of microbial activity.

Fujihara and Nakao (1982) demonstrated that the long daily eating time and the slow eating rate in sheep fed timothy hay alone could be due to high content of crude fibre, which makes it too hard for sheep to make a bolus for swallowing. Likewise, in the present experiment, there were some differences in the daily time spent eating when sheep were fed various hays. These differences might have been related to some differences in easiness with bolus, which were made from the different of hay species fed.

It is generally well known that animals usually can control to initiate and/or to cease eating feed depending on their energy balance, i.e., energy consumed and 
energy required (expenditure) for maintenance (Hidari, 1987). In the present study, the contents of digestible energy in timothy and lucerne hays, which contained relatively high nitrogen, were 2.4 and $2.6 \mathrm{Mcal} / \mathrm{Kg}$, respectively, were a little higher than that of Italian ryegrass hay $(2.2 \mathrm{Mcal} / \mathrm{Kg})$. It could be therefore, assumed that the acetic acid infused into the rumen temporarily increased energy consumption more than that required in the body. Consequently, the daily time spent eating could have been lengthened to control an energy balance in the body when timothy and lucerne hays were given to the sheep.

On the rumination appearance (the lag time after feeding), Pearce (1965) and Fujihara et al. (2002) reported that it is delayed when the ruminal $\mathrm{pH}$ value is relatively low. In this study, the ruminal $\mathrm{pH}$ value did not measured. However, similar condition as mentioned above could have occurred.

According to the report of Fujihara and Nakao (1982), daily time spent ruminating was $565.2 \mathrm{~min}$ in sheep fed on timothy hay alone (crude fibre content; $35.8 \%$ $\mathrm{DM}$ ), a longer figure than that reported here ( $427.0 \mathrm{~min}$, crude fibre content; $25.0 \%$ $\mathrm{DM}$ ). The discrepancy in these values could be due to the difference (more than $10 \%$ ) in crude fibre content of diets in the two experiments.

The fact that daily rumination time was lengthened with ruminal infusion of acetic acid in sheep fed on timothy and lucerne hays indicates some decrease the microbial activity in the rumen. The coarse particle of digesta in the rumen was more than in the control group thus the physical stimuli to the rumen wall of sheep was longer in the former than in the latter. Consequently, in feeding timothy and lucerne hays, the retention time of digesta in the rumen was lengthened by ruminal infusion of acetic acid. The digestibility of crude fibre by sheep fed on lucerne hay, however, did not change with ruminal infusion of acetic acid, and the value was very lower than that in timothy and Italian ryegrass hay fed sheep. Therefore, the effect of acetic acid infusion was not so remarkable. On the other hand, daily time spent ruminating was not changed with ruminal infusion of acetic acid in Italian ryegrass hay fed sheep, although the digestibility of crude fibre tended to decrease after ruminal infusion. The daily time spent ruminating $(580 \mathrm{~min})$ in sheep fed on Italian ryegrass hay is shown in Table 4 . This might have been a very long time as sheep were fed on a diet twice a day. Generally, this value could have been near the maximum value for daily rumination time in sheep. Consequently, it is clear from the results of this study that the animals fed on Italian ryegrass hay could not ruminate more physiologically with ruminal infusion of acetic acid. This also could explain why the digestibility of crude fibre decreased with ruminal infusion of acetic acid in sheep fed on Italian ryegrass hay.

From the results obtained in the present study, it can be concluded that the effect of ruminal infusion of acetic acid on fibre digestibility of hay diet could have a much more strong influence on the control to microbial activity than on comminuting the feed particles through remastication during the ruminating period. 


\section{ACKNOWLEDGEMENT}

Authors are very grateful to Mr. M. Asaki for his helpful assistance during the course of experiment.

\section{REFERENCES}

AOAC, 1960. Association of Official Analytical Chemists, Official Method of Analysis. $9^{\text {th }}$ Edition. Washington, DC, pp. 283-288

Egan A.R., Moir R.J., 1965. Nutritional status and intake regulation in sheep. I. Effects of duodenal infused single doses of casein, urea, and propionate upon voluntary intake of a low-protein roughage by sheep. Aust. J. Agr. Res. 16, 437-449

Fujihara T, 1980. The eating and rumination behaviour in sheep fed only grass diets in either the fresh or dried form. J. Agr. Sci. 95, 729-732

Fujihara T., 1981. Eating and rumination behaviour in sheep given silage made from the fibrous residue of ladino clover. J. Agr. Sci. 97, 485-488

Fujihara T.. Nakao T., 1982. Eating and rumination behaviour in sheep given silage made from fibrous residue of broad bean (Vicia faba L.). J. Agr. Sci. 98, 237-240

Fujihara T., Nakao T., 1990 a. The eating and rumination behaviour in sheep fed the silages made from the fibrous residues of broad bean (Viciafaba L.) and lucerne (Medicago sativa L.) with timothy (Phlemm pratense L.) hay. Jpn. J. Zootech. Sci. 61, 666-669

Fujihara T., Nakao T., 1990b. The eating and rumination behaviour in shecp fed the dict of silage made from fibrous residue left after the extraction of ladino clover (Trifolium repense L. var.giganteum) leaf protein with timothy (Phleum pratense L.) hay. Jpn. J. Zootech. Sci. 61, 757-761

Fujihara T., Maeda S., Harumoto T., 1990. The effect of ruminal infusion of VFAs on the eating and rumination behaviour in sheep fed only hay. Proceedings of $5^{\text {th }}$ AAAP Animal Science Congress, Vol. 3,87

Fujihara T. Sakaguchi M., Abdulrazak S.A., 2002. The effect of ruminal infusion of acetic and propionic acids on eating and ruminaton behaviour in sheep fed a low quality hay. J. Anim. Fced Sci. 11, 79-90

Gregory P.C., 1984. Inhibition of forestomach motility by short-chain volatile fatty acids in sheep. Can. J. Anim. Sci. 64, Suppl., 1 1-12

Gordon J.G., 1955. Rumination in the sheep. Ph.D. Thesis, University of Aberdeen (UK)

Harumoto T., Kato M., 1979. Effect of different amounts of hay intake on the rumination behaviour in sheep (in Japanese). Jpn. J. Zootech. Sci. 50, 155-160

Hidari H., 1987. In: F. Shibata (Editor). Shin-Nyuugyuuno-kagaku (in Japanese). Nousan-GyosonBunnka-Kyoukai. Tokyo, pp. 185-191

Itabisashi S., 1987. In: F. Shibata (Editor). Shin-Nyuugyuuno-kagaku (in Japanese). Nousan-GyosonBunnka-Kyoukai. Tokyo, pp. 34-35

Nakamura R.. 1980. Shin-shiryou-gaku, (No.2) (in Japanese). Chikusann-Shuppannsha, Tokyo, pp. 110-114

Pearce G.R., 1965. Rumination in sheep. 11. The circadian pattern of rumination. Aust. J. Agr. Res. 16, 635-648

Pearce G.R., Moir R.J., 1964. Rumination in sheep. I. The intluence of rumination and grinding upon the passage and digestion of food. Aust. J. Agr. Res. 15, 635-644 
Stewart C.S., 1985. Some effects of phosphate and volatile fatty acid salts on the growth of rumen bacteria. J. Gen. Microbiol. 89, 319-326

Tasaki I., Ootani I., Yoshihara I., Matsumoto T. (in Japanese), 1980. Kachiku-Shiyou-gaku, AsakuraShoten Co. Ltd., Tokyo, pp. 60-64

Taylor R.B., 1962. Pancretic secretion in the sheep. Res. Vet. Sci. 3, 63-77

\section{STRESZCZENIE}

Wplyw infuzji kwasu octowego do żwacza na pobieranie paszy i przeżuwanie u owiec żywionych sianem $\mathrm{z}$ różnych roślin

Owce otrzymywały siano z życicy wielokwiatowej, tymotki lub lucerny, zawierające odpowiednio 7,3; 10,4 i 14,9\% białka ogólnego. Kwas octowy z buforem, w łącznej ilości $1000 \mathrm{ml}$, podawano w postaci infuzji w tempie $62 \mathrm{mmol} /$ godz. ( $300 \mathrm{kcal} /$ dzień) do żwacza skopów otrzymujących siano w ilości (s.m.) 2\% masy ciała.

Stwierdzono tendencję $(\mathrm{P}>0,05)$ do obniżenia strawności substancji organicznej i związków bezazotowych wyciągowych przy infuzji kwasu, niezależnie od rodzaju skarmianego siana. Czas spędzony na pobieraniu paszy był istotnie $(\mathrm{P}<0,05)$ dłuższy u owiec otrzymujących kwas octowy i żywionych sianem z tymotki i lucerny, na skutek czego tempo pobierania paszy było u nich wolniejsze $(\mathrm{P}<0,05)$. W przypadku skarmiania siana z życicy wielokwiatowej nie wystapiły takie różnice.

Stwierdzono tendencję $(\mathrm{P}<0,05)$ do wydłużania czasu spędzonego na przeżuwaniu oraz zwiększenie dziennej liczby zwracanych kęsów u owiec żywionych sianem z tymotki i lucerny oraz otrzymujących infuzję kwasu; takich zmian nie stwierdzono przy skarmianiu życicy. Indeks przeżuwania (min/ $100 \mathrm{~g}$ pobranej s.m.) wydłużał się po infuzji kwasu i skarmianiu siana z tymotki i lucerny, natomiast nie zmieniał się, gdy owce żywiono życicą wielokwiatową.

Na podstawie otrzymanych wyników można wnioskować, że wpływ dożwaczowej infuzji kwasu octowego na strawność włókna może w znacznie większym stopniu wpływać na aktywność mikroorganizmów niż rozdrabnianie cząstek podczas przeżuwania. 